\title{
Leadership Competencies for Academic Librarians: The Importance of Development and Fund-raising
}

\section{Mark D. Winston and Lisa Dunkley}

\begin{abstract}
Private-sector research has addressed the issue of leadership competencies as a part of defining the nature of effective leadership, the leadership qualities and areas of knowledge needed by those who contribute to organizational success, and the educational preparation needed by leaders. The societal, organizational, and competitive changes affecting academic libraries point to the need for effective leadership and the identification of leadership competencies for academic librarians. This article presents a rationale for the identification of an important component of such a statement of leadership competencies in the context of the knowledge and skills associated with development and fundraising. This issue is key for professionals who play an important role in ensuring the value and viability of their employing organizations, as well as in articulating the relevance of academic library and information services to an array of potential funding sources. The research presented here describes the areas of expertise, experience, and skills associated with academic development positions in colleges and universities as a basis for identifying leadership competencies that are relevant to academic librarians and administrators.
\end{abstract}

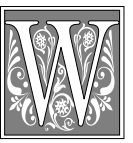

ithin the context of increasing competitiveness; limited resources; demands for greater accountability to stakeholders; the requirements of a diverse, technologically astute, and demanding user population; and organizational challenges such as changing structures and greater use of team-based decision-making, the effective organizational leadership of academic libraries is of growing importance. The study of leadership issues is necessary as a part of better defining the type of leadership needed to ensure organizational success. In this regard, the identification of leadership competencies is an important consideration as a part of identifying the educational and professional preparation needed by library leaders and of clarifying the issues to be considered in identifying those who are likely to be successful leaders. Library leaders are being called on to identify and cultivate external funding sources and solicit re-

Mark D. Winston is Assistant Professor in the School of Communication, Information and Library Studies, at Rutgers University; e-mail: mwinston@scils.rutgers.edu. Lisa Dunkley is Manager of Special Projects, Rare Books and Special Collections, in the Princeton University Library; e-mail: dunkley@princeton.edu. 
sources to support library and information services and programs. As a result, the leadership competencies associated with development and fund-raising form a necessary component of the knowledge base and skill set for those academic librarians and administrators who are expected to contribute to the success of their employing institutions by defining and articulating an organizational vision that is of interest to those outside the organization, by persuading those external funders of the value of academic library and information services, and by garnering support, including financial resources.

\section{Literature Review}

\section{Library Development and Fund-raising}

In a survey published in the winter 2000 issue of Library Trends, authors Irene M. Hoffman, Amy Sherman Smith, and Leslie DiBona noted that "Academic libraries have become active players in the fund-raising game. Over the past three years, we have witnessed a tremendous growth in fund-raising activities across the United States and Canada." ${ }^{1}$ Librarians and library administrators increasingly are becoming responsible for garnering resources from external sources as a part of their budgets. There is abundant literature that addresses this increasingly important leadership activity, but a dearth of articles on the knowledge and skills that librarians need to possess to be effective fundraisers.

The published library and information science literature related to development and fund-raising in academic libraries falls into a number of broad categories, such as types of funding sources, funding methods, and case studies. The literature related to funding sources identifies funding opportunities that are available when librarians and library administrators seek new sources of income, including opportunities they can create themselves, and provides tips on discovering new fund-raising sources. ${ }^{2,3}$ Individuals and groups with which libraries might partner to their mutual benefit are addressed in this aspect of the literature, as well. Although the formation and management of Friends groups as sources for fund-raising and development are considered, for example, as is the relationship between college sports programs and library fund-raising, ${ }^{4}$ Robert Wedgeworth observed in Library Trends,

Fund-raising is not a well-researched activity. Within the library field there is even less upon which to base the development of a philosophy of fund-raising.... Campus-wide fundraising personnel have directed most academic library fund-raising. Most [of them] are guided by external consultants that almost uniformly recommend against separate library subcampaigns and library fund-raising professionals. ${ }^{5}$

It appears that one of the most effective ways for librarians to raise funds is for them to be their own advocates.

The literature related to funding methods includes descriptions of how fundraising operations in libraries can be organized, as well as cautionary articles. ${ }^{6}$ For example, a two-part article entitled "When Fund-raising Is Too Innovative" describes the dangers associated with some creative fund-raising ideas, which, if handled improperly, may subject the institution to income taxes and put its taxexempt status at risk. ${ }^{78}$ In addition, case studies provide information relating to how librarians and administrators have undertaken the fund-raising process, including the results of interviews that shed light on the success individual organizations have realized. ${ }^{9,10}$

Of the extensive body of literature on development and fund-raising in academic libraries, the research literature does not address the knowledge and the skill set that librarians need to be effective fundraisers for their organizations. In "Factors for Success: Academic Library Development Survey Results," Hoffman, Smith, and DiBona described the characteristics and elements of a fund-raising 
program within the California State University system. The authors administered a survey to identify these elements and presented findings in a number of areas, including the age of the program, the size of the donor pool, the involvement of the library director, the type of institution, and the effectiveness of Friends groups within the annual giving program. In addition, they found that programs with the highest goals raised the most money, programs connected to the "central advancement effort" raised substantially more funds, and the most successful directors had four or more years of fundraising experience. ${ }^{11}$ The research indicates that professional development is highly advantageous to library directors' fund-raising efforts.

With the exception of the issues of communication and organizational vision, the leadership competencies that have been considered relate most closely to internal, as opposed to external, roles.

It appears that the educational preparation offered in most graduate library and information science (LIS) programs does not address issues of development and fund-raising to a large extent. The content of marketing courses in the ALAaccredited LIS programs in the United States are likely to be most closely related to issues involving development and donor relations. The topic areas covered in such courses include issues such as marketing principles and theory, market analysis, the design of services for special populations, public relations, marketing research, communication techniques, and fund-raising. Such course work is included in the curricula of only 33.3 percent of the LIS programs. Moreover, marketing courses are not required of all students in any of the programs. ${ }^{12}$ However, management course work, which may address development and fund-raising to a certain extent as well, along with many other issues, is offered in all of the LIS programs. $^{13}$

\section{Leadership Competencies}

For a number of years, the study of organizational theory has included the identification of leadership competencies for those who are expected to take on leadership roles in private-sector organizations. The statement of leadership competencies has been intended to "identify a small set of attributes that successful leaders possess, articulate them in ways that could be transferred across all leaders, and create leadership development experiences to ensure that future leaders possess these attributes."14 Thus, the discussion of leadership competencies helps to define the nature of effective leadership, identify "leadership competency gaps for the... leadership team" in an organization, and identify the components of leadership education and development that are relevant to the needs of organizations. ${ }^{15}$ Such statements have included the identification of leadership competencies such as "adaptability, effective interpersonal communication, and good decision making."16 Other leadership competencies, which have been identified as important but have been described as potentially too general by some researchers, include the ability "to act with integrity, set a vision, have energy, execute strategy, and energize others."17

Recent literature on the topic of leadership competencies has focused on the need to expand the focus to include global leadership competencies, such as renewed attention to understanding and valuing diversity and better understanding and "knowing customers." 18,19 In addition, particular attention is being paid to the development of leadership competency models that are organization specific, including the unique organizational requirements and strategies that have an impact on the leadership needs for the company in question. ${ }^{20,21}$

Leadership competencies are considered to be important in the achievement of organizational goals, particularly when the competencies are organization specific, for a number of reasons, including:

1. They guide direction. 
2. They are measurable.

3. Competencies can be learned.

4. They can distinguish and differentiate the organization.

5. They can help integrate management practices. ${ }^{22}$

\section{Leadership Competencies in Library and Information Science}

To a large extent, there is a compelling rationale for the development of a statement of leadership competencies in academic librarianship on the basis of various changes in the environment external, as well as internal, to libraries. In the context in which libraries operate, these factors include:

- increased accountability for all types of organizations;

- increased competition;

- changing organizational structures;

- the proliferation of team-based decision-making and participative management;

- the proliferation of technological applications in the provision of information services;

- the advent of the learning organization model;

- the increasingly diverse client base and talent pool;

- greater responsibility being placed on library administrators to secure growing portions of their resources from sources outside the parent organization or primary funding source.

These factors are associated with the need to focus on defining leadership competencies and on identifying and preparing leaders who possess them.

Although there are a number of examples of professional organizations in library and information science that have developed statements of professional competencies for information professionals, including the consideration of leadership in specific professional settings, the development of a statement of leadership competencies for the profession generally or with regard to particular types of settings (such as academic libraries) has been addressed to a very limited extent. ${ }^{23}$ The ad- vent of the learning organization model has prompted the identification of core competencies associated with the recruitment of candidates, development of knowledge and skills, and evaluation of success in areas such as analytical skills and decision-making, communication skills, organizational skills, and budget management, as well as leadership. ${ }^{24}$ There have been numerous examples of statements of core competencies by type of library. However, these competencies have not focused on leadership but, rather, on other important areas of professional knowledge and of skills needed, for the most part. For example, statements related to public libraries include a definition of competencies by "product areas," such as reference and children's services, focusing on issues such as collection development skills, cataloging and classification, and user services skills. ${ }^{25}$ With regard to academic libraries, there have been examples of competencies developed in association with library functional areas as well, most notably, reference services and collection development. ${ }^{26,27}$

In addition, the first steps in the development of a statement of leadership competencies have included the consideration of specific managerial competencies. Generally, these competencies have come in the form of components of overall statements of competencies for senior managers, which have included leadership issues as well as more specific managerial competencies such as budget management, personnel management, and planning. ${ }^{28}$ Leadership competencies that have been identified as important for leaders in LIS have focused on issues of defining and achieving an organizational vision, mentoring, modeling valued behaviors, and effective interpersonal communication. ${ }^{29}$

With the exception of the issues of communication and organizational vision, the leadership competencies that have been considered relate most closely to internal, as opposed to external, roles. Certainly, the development and articulation of a relevant and compelling organizational vi- 
sion to donors and other external funding sources is an important aspect of the leadership role in academic libraries.

In light of the importance of the development responsibilities that are or will become a part of the academic library administrator's portfolio, it is appropriate to consider the identification of leadership competencies that focus on the academic librarian's or administrator's work with external constituencies in greater detail. In this regard, one important component of such a statement would relate to the areas of knowledge and the skills associated with successful donor relationship-building and fund-raising.

The research presented here addresses the types of skills, knowledge, and experience that are beneficial for those who have responsibilities associated with development for the larger parent institution in the academic environment. Although the published literature associated with development and libraries addresses the issues identified above, a more comprehensive statement of the nature of the responsibilities related to development is needed. First, it is important to identify the types of qualifications in terms of prior professional experiences and educational preparation and competencies that would be of benefit to those in leadership roles who have development responsibilities in college and university libraries. In addition, there is the need to inform LIS education with regard to the types of leadership competencies that should be considered in the preparation of those who will assume those roles in libraries. The study of those who have primary responsibility for development and fund-raising and who often advise, work with, or assist academic library administrators in their development efforts will be considered in this research.

\section{Methodology}

It was determined that the study of job announcements for administrative positions in academic libraries would provide some basis for the consideration of qualifications and responsibilities related to development. Libraries have relatively few development positions. In many cases, library development is assigned to a staff member within the college or university's development office-someone who is likely to have other responsibilities, academic units, and constituencies to attend to as well. In addition, the job announcements for the positions of library dean, director, or university librarian must address so many different types of responsibilities and areas and levels of experience, as well as competencies, that the issue of development is not likely to be treated in detail. Thus, job announcements for positions associated with development at the college or university level were selected as the source of data for the research on the basis of the more complete and explicit presentation of data related to both responsibilities and qualifications. Although not all of the data might apply directly to administrative positions in libraries, a more complete and definitive statement of the aspects of this leadership competency that is gaining importance in libraries would be of the most benefit to those interested in the educational and professional preparation of leaders in library and information science.

To gather data for the study, the researchers analyzed job announcements for academic development positions published over a six-month period. All of the advertisements listed under the "Development" heading in the "Bulletin Board" section of the Chronicle of Higher Education during the six-month period of January through June 2000 were examined. ${ }^{30}$ The basis for the identification of this time period was the need for inclusion of one of the periods (spring) during which there is an extensive number of job listings, representing a high level of recruitment for the subsequent academic year. In addition, the Chronicle of Higher Education was selected over sources such as the Chronicle of Philanthropy or Council for the Advancement and Support of Higher Education (CASE) publications because of its frequency of publication (i.e., weekly), the extensive number of job announcements 
in it, and the greater likelihood of its including job announcements for different types of institutions.

Data collection was restricted to display advertisements for development positions in four-year colleges and universities in the United States. The Chronicle of Higher Education also includes development positions for other types of organizations, including philanthropic organizations, museums, secondary schools, zoos and aquariums, executive recruitment firms, the U.S. Olympic Committee, Special Olympics, religious groups, and public radio and television stations, among others. However, these types of organizations were not included in the data-gathering or analysis because of their lack of applicability to this research. The display advertisements, as opposed to the shorter recruitment advertising, were used because of the inclusion of an appropriate amount of information on the positions to contribute to the analysis. All job announcements that met the criteria were included. Some of these may represent repeat advertisements for a position, either identical to the first or slightly revised; others may be a series of ads for different positions at the same institution, but carrying the same title. Because of the difficulty in discerning the differences between them, all examples were included.

For each of the job announcements, data were gathered on the institution, the qualifications, and the job responsibilities. The academic institutions were categorized on the basis of the Carnegie classification, with four categories being used:

1. Two-year Colleges (associate degree-granting)

2. Four-year Colleges (baccalaureate degree-granting)

3. Regional Universities

4. Research Universities ${ }^{31}$

For the purposes of comparability, only the three types of four-year institutions were included in the analysis. Information on whether the institutions are public or private, as well as the specific job titles, also was gathered. The responsibilities identified in the job announcements (such as stewardship, li- aison activities, management, planning, and grant-writing) as well as the requirements (in terms of knowledge, skills, and experience) were considered and quantified for the analysis and discussion. In total, 432 job announcements were included in the study and the results presented. A number of types of correlational analyses were undertaken to determine the extent to which various factors, such as type of institution and position title, had an impact on the requirements and responsibilities associated with the various positions.

\section{Findings and Discussion Job Title}

The most frequently identified job title for the positions studied was that of director or executive director, which appeared in $229(53.0 \%)$ of the positions (see table 1 ). Associate/assistant director positions represented sixty-one $(14.1 \%)$ of the announcements, followed by the officer in fifty-one $(11.8 \%)$ and vice president in forty-four $(10.2 \%)$. The least frequently mentioned titles were assistant/associate vice president, vice/associate chancellor, and associate provost. These appeared in a total of twenty-seven cases $(6.3 \%)$. Fourteen announcements (3.2\%) fell into the category of "other," which included titles such as proposal writer and research associate.

Thus, on the basis of the responsibilities involved in the positions and the

\begin{tabular}{|c|c|}
\hline \multicolumn{2}{|c|}{$\begin{array}{c}\text { TABLE } 1 \\
\text { Job Titles Associated with } \\
\text { Development }\end{array}$} \\
\hline Title & $\begin{array}{c}\text { Percentage } \\
\text { of Total }\end{array}$ \\
\hline Director/executive director & $53.0 \%$ \\
\hline Assistant/associate director & $14.1 \%$ \\
\hline Development officer & $11.8 \%$ \\
\hline Vice president & $10.2 \%$ \\
\hline $\begin{array}{l}\text { Assistant/associate vice } \\
\text { president/chancellor }\end{array}$ & $6.3 \%$ \\
\hline Assistant/associate dean & $0.2 \%$ \\
\hline Other & $3.0 \%$ \\
\hline
\end{tabular}


likely reporting structures, the data reveal that most $(78.9 \%)$ of the positions available in this six-month period were midor lower-level professionals.

\section{Nature of Institution}

The colleges and universities were categorized on the basis of the Carnegie classification.

As previously stated, Category 1 institutions (two-year colleges, or associate degree-granting institutions) were not included in the analysis. Category 2 is composed of four-year colleges (Baccalaureate I and II institutions). Category 3 institutions are "Master's (comprehensive) colleges and universities I and II." For the purpose of the analysis, the terminology "research institutions" has been used to include two types of institutions: Research Universities I and II and Doctoral Universities I and II. ${ }^{32}$

The largest number of job announcements (190, or $44 \%$ ) represented institutions in the research university category (see table 2). The others were almost evenly divided between four-year colleges and comprehensive universities ( $27.3 \%$ and $23.4 \%$, respectively), with the remaining institutions being two-year colleges. It should be noted that job announcements for academic units were categorized in their broader contexts on the basis of the fact that, in many cases, the advertised position may be for a particular school or other academic unit, but the development officer is often part of the university-wide development team. For example, the Columbia University School of Nursing (CSN) is part of Columbia University and Eastman School of
Music is part of the University of Rochester. Therefore, CSN and Eastman would be categorized as research institutions. In addition, the requirements for development positions in academic units of colleges or universities are likely to reflect the specific nature and demands associated with the particular type of academic setting, as is the case for library administration positions. A very small number of schools fell outside these categories, such as a seminary, which is not part of a larger institution of higher education.

The larger percentage of schools in the Research University category may reflect the fact that the research institutions have more fully developed development programs, broader needs, or larger and more specialized staffs than is the case for the other types of institutions. These more complex organizations may have more complicated funding needs, as well.

\section{Public and Private}

Because funding needs and sources are different for public and private institutions, it was important to identify this type of data for each college or university. As shown in table 2, the majority of institutions (232, or $54.5 \%$ ) are private and another 194 are public (45.5\%). A number of types of correlational analyses were undertaken to determine whether there were distinctions in terms of the qualifications and responsibilities on the basis of the nature of the institution.

\section{Development Responsibilities}

A number of types of development responsibilities have been identified as important for the positions studied in this

\begin{tabular}{|lcc|}
\hline \multicolumn{2}{c|}{$\begin{array}{c}\text { TABLE 2 } \\
\text { Nature of the Institutions }\end{array}$} \\
\hline \hline Type of Institution & Number of Positions & Percentage of Total \\
\hline Baccalaureate & 118 & $27.3 \%$ \\
Master's (comprehensive) & 101 & $23.4 \%$ \\
Research or doctoral & 190 & $44.0 \%$ \\
Public & 194 & $45.5 \%$ \\
Private & 232 & $54.5 \%$ \\
\hline
\end{tabular}




\begin{tabular}{|lcc|}
\hline \multicolumn{3}{c|}{ TABLE 3 } \\
\hline \multicolumn{3}{|c|}{ Development and Fund-raising Responsibilities } \\
\hline Responsibility & Number of Positions & Percentage of Total \\
\hline Stewardship and donor cultivation & 240 & $55.6 \%$ \\
Development planning & 240 & $55.6 \%$ \\
Management of development staff & 112 & $26.2 \%$ \\
External liaison & 109 & $25.2 \%$ \\
Internal liaison & 76 & $17.8 \%$ \\
Work with Friends & 38 & $8.9 \%$ \\
Development of reports & 34 & $8.0 \%$ \\
Grant-writing & 19 & $4.4 \%$ \\
Organization of volunteer groups & 16 & $3.7 \%$ \\
Private & 232 & $54.5 \%$ \\
\hline
\end{tabular}

research. In more than half (240, or 55.6\%) of the job announcements, "identification, cultivation, solicitation, and stewardship" of donors was cited, making it the category of responsibility that appeared most frequently in these advertisements (see table 3). An equal number of cases (240, or $55.6 \%$ ) included the key words planning or strategizing in their descriptions.

Other responsibilities appeared less frequently, including managing staff (112, or $26.2 \%)$, acting as a liaison with external individuals and organizations $(109$, or $25.2 \%$ ), and acting as an internal development liaison with other parts of the university (76 cases, or $17.8 \%$ ).

Other responsibilities were notable for how seldom they appeared. In only sixteen cases $(3.7 \%)$ was the formation of, and work with, volunteer committees cited as part of the job responsibilities. It is surprising to note that grant-writing also was seldom cited $(19$, or $4.4 \%)$. In addition, reports and other communications activities were among the least-cited responsibilities (34 cases, or $8.0 \%$ ). Working as the chief liaison with the Friends groups was listed in only thirty-eight cases $(8.9 \%)$.

Responsibilities that fell into the category of "other" included working with advisory councils, motivating volunteers, conducting prospect research, and working with athletic promotions and sponsorships, among others. ${ }^{33}$

\section{Development Qualifications}

The job announcements were analyzed to determine what types of qualifications and experience were identified in association with the positions. "Previous experience" in development was cited more than any other quality and mentioned in nearly three-quarters of the job announcements (see table 4). The next most frequently cited qualifications were written and oral communication skills (59.3\% and $53.2 \%$, respectively). There was a significant drop-off between these skills and the next most frequently mentioned, interpersonal skills ( $28.8 \%$ ), followed by previous management experience $(19.9 \%)$, organizational skills ( $16.9 \%)$, and evidence of being a team player $(15.5 \%)$.

Eight qualifications were mentioned less than ten percent of the time: leadership skills (9.8\%), strategic planning skills and experience $(8.2 \%)$, presentation skills $(4.9 \%)$, ability to motivate volunteers $(4.7 \%)$, vision $(4.2 \%)$, previous experience with budgets $(3.7 \%)$, and flexibility $(1.4 \%)$.

Qualifications that fell into the category of "other" included the willingness and ability to travel often and comfort with computer software and applications. Other examples in this category included commitment to higher education, ability and willingness to build effective relationships with varied constituencies, knowledge of the local geographic community, high energy, listening skills, creativity, and the ability to meet deadlines. 
To determine the extent to which there were significant differences in the qualifications associated with the positions on the basis of job title, correlational analyses were undertaken.

\section{Educational Qualifications}

The level of education and the amount of previous experience specified in the job advertisements also were considered. In 298 cases $(70.0 \%)$, the advertisements specified that applicants needed to have a bachelor's degree. In 167 cases (30.0\%), a master's degree was listed as a desirable credential, but those candidates with only the bachelor's degree would not be excluded from consideration (e.g., “bachelor's degree required, master's preferred"). In cases in which the employer noted "bachelor's required, master's preferred," these jobs were counted in both categories. The next most-requested level was a master's degree (e.g., "master's required"), which was indicated in 168 cases $(39.3 \%)$. The master's degree category includes other professional degrees as well. Law and business degrees were most frequently identified. Seven cases (1.64\%) specified a doctorate, and most of these were at the vice president level.
Although many of the advertisements specified previous experience, using numbers of years, not all did so. Most of the positions advertised required five years of experience or fewer; 173 cases $(40.6 \%)$ fall into this group. Between five

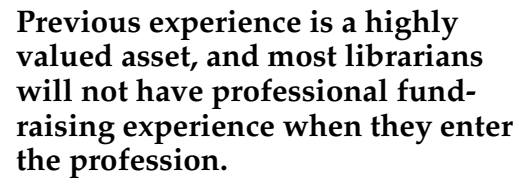

and ten years of experience were sought in 106 cases $(24.9 \%)$, and ten or more years of experience were sought for twentyeight positions, or 6.6 percent. A small number of positions specified that a combination of a bachelor's degree and a longer period of experience were equivalent to a master's degree with fewer years.

\section{Summary and Conclusion}

The statement of leadership competencies represents a critical component of the articulation of the nature of effective leadership in any professional arena or type of organization. This is certainly the case with regard to academic libraries, which face many challenges in the current societal,

\begin{tabular}{|lcc|}
\hline \multicolumn{3}{c|}{ TABLE 4 } \\
Position Qualifications \\
\hline \hline Qualification & Number of Positions & Percentage of Total \\
\hline Stewardship and donor cultivation & 240 & $56.2 \%$ \\
Previous development experience & 312 & $73.1 \%$ \\
Written communication skills & 253 & $59.3 \%$ \\
Oral communication skills & 227 & $53.2 \%$ \\
Interpersonal skills & 123 & $28.8 \%$ \\
Previous management experience & 85 & $19.9 \%$ \\
Organizational skills & 72 & $16.9 \%$ \\
Evidence of being a team player & 66 & $15.5 \%$ \\
Leadership skills & 42 & $9.8 \%$ \\
Strategic planning skills and experience & 35 & $8.2 \%$ \\
Presentation skills & 21 & $4.9 \%$ \\
Persuasion & & \\
(ability to motivate volunteers) & 20 & $4.7 \%$ \\
Vision & 18 & $4.2 \%$ \\
Previous budget experience & 16 & $3.7 \%$ \\
Flexibility & 6 & $1.4 \%$ \\
\hline
\end{tabular}


economic, and organizational context. Particularly for those individuals who desire to become senior library administrators, the leadership roles of library dean, director, or university librarian are increasingly inclusive of responsibilities related to development and fund-raising. The consideration of leadership competencies is important in terms of the extent to which those who progress professionally in academic libraries will possess the knowledge and skills to be competitive for such positions and to be successful in them.

In terms of the leadership competencies associated with development and fund-raising, the roles and responsibilities are becoming increasingly important in the academic environment overall and in academic libraries in particular. However, it is not clear that the externally focused leadership competencies related to development, donor relations, and fundraising have been clearly defined in the context of academic libraries or that the professional experiences, academic study, and professional development that most librarians receive will prepare them for the leadership roles in this area. The data suggest that today's fund-raising professional needs to be able to identify gift opportunities through strategic planning, to create successful solicitation and cultivation plans, and to provide stewardship to donors. This selection of advertisements suggests that these responsibilities are fundamental to development positions.

Librarians with fund-raising responsibilities should have similar competencies. In a library setting, obtaining these requisite skills can be challenging. Previous experience is a highly valued asset, and most librarians will not have professional fund-raising experience when they enter the profession. Yet, they need to have these skills to be successful in future leadership roles. Although academic librarians are likely to develop expertise in some areas that appear to be important with regard to development responsibilities, such as managing staff and written, oral, and interpersonal communica- tion, issues such as cultivation of relationships with donors and previous development experience are not likely to be part of the responsibilities of those librarians progressing through the professional ranks.

In this regard, the results associated with the area of responsibility and the professional experience associated with planning are difficult to interpret. It is striking that the importance of strategic planning ability as a qualification (8.2\%) is not consistent with the frequency of the requirement of previous development experience $(73.1 \%)$ or the professional responsibility in this area indicated for the advertised positions (56.2\%). With such an emphasis on previous experience, it may be that employers are able to gauge the extent of the applicants' abilities in strategic planning based on prior positions held and interview performance. This "disconnect" suggests that applicants can have previous experience in development but not have to demonstrate their abilities to develop solicitation plans, even though "planning skills" appear in more than half of the advertisements (55.6\%). Knowledge and experience in strategic planning, in general, if not associated with development planning, in particular, are likely to be areas in which academic librarians are able to develop and demonstrate their competency based on the nature of professional responsibilities in middle managerial roles in libraries.

Thus, although a number of the qualifications identified in relation to the development positions are related to specific types of professional experience, many relate to various aspects of communication, management, marketing, and leadership, including organizational ability, strategic planning, persuasion, and vision. It certainly seems to be the case that many of these issues are appropriately addressed in course work included in graduate LIS programs.

In addition, within the professional ranks, there should be opportunities for academic librarians to develop many of the leadership competencies associated 
with development and fund-raising. These opportunities include professional development opportunities provided by professional associations, colleges, and universities; mentoring relationships with library administrators with development experience and expertise and with development professionals; and opportunities to "shadow" the institution's development professionals on actual solicitation calls, for example.

As more and more organizations vie for gifts among donors, library fund-rais- ing demands skilled library leaders with a thorough knowledge of the development process.

The question of the extent to which those who are progressing in their careers in academic libraries would have the opportunity to gain the professional experiences needed to take on responsibilities associated with development as they compete for senior managerial positions helps to form the basis for the need to identify and articulate leadership competencies in this area.

\section{Notes}

1. Irene M. Hoffman, Amy Sherman Smith, and Leslie DiBona, "Factors for Success: Academic Library Development Survey Results," Library Trends 48 (2000): 540.

2. Jennifer Paustenbaugh and Lynn Trojahn, "Annual Fund Programs for Academic Libraries," Library Trends 48 (winter 2000): 579-96; Annette Thibodeaux, "Finding Dollars for Technology and More: A List of Books, Videos and Other Sources," Book Report 16 (Mar./ Apr. 1998): 1820 .

3. Emma Bradford Perry, “Winning Money: A Team Approach to Grant Writing at Southern University in Baton Rouge," Computers in Libraries 20 (May 2000): 32-36; David King, "Soliciting Virtual Money," Library Journal (fall 2000): 39-41.

4. James G. Neal, "College Sports and Library Fundraising, " Bottom Line 10 (1997): 58-59; Robert Wedgeworth, "Donor Relations as Public Relations: Toward a Philosophy of Fund-raising for Academic Libraries," Library Trends 48 (winter 2000): 530-39.

5. Wedgeworth, "Donor Relations as Public Relations." 530.

6. Susan K. Martin, "Academic Library Fund-raising: Organization, Process and Politics," Library Trends 48 (winter 2000): 560-78; Terry L. Kirchner, "Advocacy 101 for Academic Librarians: Tips to Help Your Institution Prosper," College \& Research Libraries Neww 60 (Nov. 1999): 844$46+$.

7. Herbert W. Snyder, "When Fund-Raising Is Too Innovative: Part I: Avoiding Unrelated Business Income," Library Administration \& Management 12 (winter 1998): 26-32.

8. —, "When Fund-raising Is Too Innovative: Part II: Protecting Your Tax-exempt Status," Library Administration \& Management 12 (winter 1998): 33-38.

9. Susan K. Martin, "The Changing Role of the Library Director: Fund-raising and the Academic Library," Journal of Academic Librarianship 24 (Jan. 1998): 3-10.

10. Eric W. Johnson, "Fund-raising and the Library Director: An Interview with Susan Kent," Library Administration \& Management 12 (summer 1998): 129-31.

11. Hoffman, Smith and DiBona, "Factors for Success," 540-59.

12. Mark Winston and Gretchen Ebeler, "Leadership Competencies in Library and Information Science: Marketing as a Component of LIS Curricula," Under consideration for publication.

13. Ibid.

14. D. Ulrich, J. Zenger, and N. Smallwood, "Building Your Leadership Brand," Leader to Leader (winter 2000): 40-46.

15. Robert Barner, "Five Steps to Leadership Competencies," Training \& Development 54 (Mar. 2000): 51.

16. Ibid.

17. Jim Intagliata, Dave Ulrich, and Norm Smallwood, "Levering Leadership Competencies to Produce Leadership Brand: Creating Distinctiveness by Focusing on Strategy and Results," Human Resource Planning 23 (2000). Cited 30 April 2001. Available online from http:// proquest.umi.com/pqdweb.

18. Christopher B. Bingham, Teppo Felin, and J. Stewart Black, "An Interview with John Pepper: What It Takes to Be a Global Leader," Human Resource Management 39 (summer/fall 2000): 287-92; Bill J. Bonnstetter, "The DNA of Global Leadership Competencies," Thunderbird International Business Review 42 (Mar./Apr. 2000): 131-44. 
19. Bingham, Felin, and Black, "An Interview with John Pepper," 287.

20. Allen J. Morrison, "Developing a Global Leadership Model," Human Resource Management 39 (summer/fall 2000): 117-31; Margaret E. Alldredge and Kevin J. Nilan, "3M's Leadership Competency Model: An Internally Developed Solution," Human Resource Management 39 (summer/fall 2000): 133-45.

21. Barner, "Five Steps to Leadership Competencies," 48.

22. Intagliata, Ulrich, and Smallwood, "Levering Leadership Competencies to Produce Leadership Brand."

23. Special Libraries Association, Competencies for Special Librarians of the 21st Century (Washington, D.C.: Special Libraries Association, 1996). Cited 1 May 2001. Available online from http:/ /www.sla.org/content/professional/meaning/comp.cfm. Young Adult Library Services Association, "Competencies for Librarians Serving Young Adults," Teacher Librarian 27 (2000): 64-65.

24. Joan Giesecke and Beth McNeil, "Core Competencies and the Learning Organization," Library Administration \& Management 13 (summer 1999): 158-66.

25. Richard J. Naylor, "Core Competencies: What They Are and How to Use Them," Public Libraries 39 (Mar./Apr. 2000): 108-14.

26. Candace R. Benefiel, Jeannie P. Miller, and Diana Ramirez, "Baseline Subject Competencies for the Academic Reference Desk," Reference Services Review 25, no. 1 (1997): 83-93; Cecilia D. Stafford and William M. Serban, "Core Competencies: Recruiting, Training and Evaluating in the Automated Reference Environment," Journal of Library Administration 13, nos. 1/2 (1990): 81-97.

27. Margaret Ann Johnson, "Dollars and Sense in Collection Development: Skills and Competencies for Collection Development and Management," Technicalities 19 (May 1999): 1, 7-9.

28. Suzanne H. Mahmoodi and Geraldine King, "Identifying Competencies and Responsibilities of Top Management Teams in Public Libraries," Minnesota Libraries 30 (autumn/winter 1991/1992): 28.

29. Ibid., 27-28, 31.

30. Chronicle of Higher Education 46 (Jan. 7, 2000-June 30, 2000).

31. All of the schools were coded according to their listings in A Classification of Institutions of Higher Education: 1994 Edition (Princeton, N.J.: Carnegie Foundation for the Advancement of Teaching, 1994).

32. The schools in the Baccalaureate I category award more than 40 percent of their degrees in liberal arts fields and are restrictive in admission. The Baccalaureate II colleges award less than 40 percent of their degrees in liberal arts and are less restrictive in admission. These colleges offer a full range of baccalaureate programs and are committed to graduate education through the master's degree. Level I institutions grant forty or more degrees annually in three or more disciplines; Level II institutions grant twenty or more degrees in one or more disciplines. The research universities offer a full range of baccalaureate programs. They are committed to graduate education through the doctorate, awarding fifty or more doctoral degrees each year. They differ in their level of federal support: Level I institutions receive more than $\$ 40$ million each year; Level II institutions receive between $\$ 15.5$ and $\$ 40$ million. The doctoral universities offer a full range of baccalaureate programs and are committed to graduate education through the doctorate. The Level I institutions offer at least forty doctoral degrees each year in five or more disciplines; Level II schools offer ten doctoral degrees in three or more disciplines or more than twenty doctoral degrees in one or more disciplines.

33. As a result of the likelihood of distinctions in terms of responsibilities, based on the job titles associated with the positions, a number of types of correlational analyses were undertaken. Because the basis for the research is to begin to develop a comprehensive statement of the nature of knowledge and skills that would form the basis for leadership competencies related to development in academic library positions, the correlational analyses would not serve to be exhaustive but, rather, illustrative for positions that focus on development and fund-raising exclusively. Thus, the descriptive statistical results are presented here. Differences based on job titles provide a level of detail that is not the focus of this discussion. In addition, all of the institutions considered are four-year colleges or universities. Although there are distinctions with regard to qualifications and responsibilities associated with development positions in the different types of institutions, including public and private colleges and universities, the basis for this research is to identify leadership competencies overall, as opposed to those that are type of institution specific. 